\title{
İç ve Dış Müşteriler Açısından Kabin Hizmetleri Kalite Algısını Ölçmeye Yönelik Karşılaştırmalı Bir Araştırma*
}

\begin{abstract}
Akın AKPUR ${ }^{* *} \odot$
Öz

Burhanettin ZENGiN ${ }^{* * *}$

Havayolu taşımacılığı, turizmin temelini oluşturan en önemli dinamiklerinden biridir. Sivil hava taşımacılığının 1950'lerden itibaren gösterdiği gelişme ile uzak mesafelere hızlı, güvenli ve ekonomik ulaşım sağlanmıştır. Küreselleşme ve liberalleşme ile birlikte dünyada birçok özel havayolu işletmesi piyasaya girerek havayolu taşımacılığında yoğun rekabet ortamını oluşturmuştur. Rekabetin en önemli araçlarından biri yüksek hizmet kalitesidir. Çalışmanın amacı; yolcu ve kabin ekiplerinin hizmet kalitesi algıları ölçülmeye çalışılarak, iç ve dış müşterilerin kabin hizmetlerine ilişkin kalite algılarını ortaya çıkarmaktır. Bu araştırma Türkiye'nin ilk ve en büyük düşük maliyetli (low-cost) özel bir havayolu işletmesinin yolcu ve kabin ekipleri ile yapılmıştır. Bu çalışma, nicel bir araştırma olarak tasarlanmış olup veri toplama aracı olarak anket tekniğinden yararlanılmıştr. Tesadüfi olmayan örnekleme yöntemlerinden kolayda örnekleme yöntemi ile 456'sı yolcu 264'ı kabin ekibi olmak üzere toplam 720 anketten veriler elde edilmiştir. Verilerin analizinde SPSS istatistiksel analiz programından yararlanılmış- tır. Faktör analizi, frekans analizi, korelasyon analizi, Kruskal Wallis Testi, Mann Whitney U testi, bağımsız iki değişkenli t testi ve tek yönlü Anova testi kullanılarak bulgular analiz edilmiştir. Araştırmanın sonuçlarına göre kabin ekiplerinin, hizmet kalitesini yolculara göre daha yüksek algıladıkları, yolcuların eğitim düzeylerinin hizmet kalitesi algısını etkilemediği fakat kabin ekiplerinin eğitim düzeyleri ile hizmet kalitesi algıları arasında anlamlı fark olduğu sonucuna ulaşılmıştır
\end{abstract}

Anahtar Kelimeler: Hizmet Kalitesi, Servperf, Havayolu, Kabin Memuru.

\section{A Comparative Study to Measure Cabin Services Quality Perception of Internal and External Costumers}

\begin{abstract}
Air transport is one of the most important dynamics of tourism. Since development of civil air transportation since the 1950s, fast, safe and economical transportation has been achieved at long distances. With globalization and liberalization, many private airline companies in the world have join the market and created an intense competition environment in airline transportation. One of the most important tools of competition is high service quality. The aim of the study is to determine the quality perceptions of the cabin crew (internal costumers) and passengers (external costumers) regarding

\footnotetext{
Bu çalışma Düzce Üniversitesi tarafindan düzenlenen 17. Geleneksel Turizm Sempozyumunda sunulmuş ve bildiri kitabında bildiriden yararlanılarak hazırlanmıştr.

** Doktora Öğrencisi, Sakarya Üniversitesi, Sosyal Bilimler Enstitüsü, Turizm İşletmeciliği Bölümü, aakpur@gmail.com

*** Doç. Dr., Sakarya Üniversitesi, Turizm Fakültesi, Turizm Rehberliği Bölümü, bzengin@sakarya.edu.tr

(c) Sorumlu Yazar
} 
cabin services by trying to measure the quality of service perceptions. The survey was carried out by passenger and cabin crews of Turkey's first and largest low-cost private airline company. This study was designed as quantitative research and the survey technique was used as a data collection tool. The data were obtained from 720 surveys, 456 of which were passenger, 264 of which were cabin crew with convenient sampling method from non-random sampling methods. Statistical analysis was performed using SPSS statistical analysis program. In the analysis, factor analysis, frequency analysis, correlation analysis, Kruskal Wallis test, Mann Whitney $U$ test, independent t-test and one-way ANOVA test were used. According to the results of the study, the perceived service quality of the cabin crews is higher than the service quality perception of the passengers. It is concluded that although the level of education of passengers did not affect their perception of service quality, there is significance difference between the level of cabin crew education and their perception of service quality.

Keywords: Service Quality, Servperf, Airline, Cabin Attendant.

\section{Gíriş}

Jet motorlu uçakların faaliyete geçmesinden sonra havayolu taşımacılığındaki büyümeye bağlı olarak dünyada havayolu ulaşımını tercih eden kişi sayısı artmış ve 2016 yılı itibarı ile sivil havayolu taşımacılığı 3,8 milyar kişinin seyahat ettiği dev bir sektör haline gelmiştir (WEB1).

Türkiye'de liberalleşme ile birlikte faaliyet gösteren özel havayolu işletmelerinin sayısı artmış buna bağlı olarak yoğun bir rekabet dönemine girilmiştir (Göktepe, 2007: 213). Havayolu işletmeleri rakiplerine karşı ayakta kalabilmek için mevcut müşterilerini elde tutmalı ve yenilerini kazanmalıdır. Bu da ancak müşterilere yüksek hizmet kalitesi sunarak sağlanabilir. Hizmet kalitesi müşteri bağlılığını hem doğrudan hem de dolaylı olarak pozitif yönlü etkilemektedir (Usta ve Memiş, 2009: 87).

Havayolu taşımacılı̆ında hizmet veren personel (kontuar personeli, kabin görevlileri vb.) ve sunulan fiziksel kanıtlar (koltukların konforu, sunulan yiyecek ve içecekler) hizmet kalitesi algısında önemli etkiye sahiptir. Bir havayolu işletmesinde, yolcular ile en çok iletişim içerisinde olan iş görenler, genellikle havayolu reklamlarında güler yüzlülükleri ve misafirperverlikleri vurgulanan kabin ekipleridir (WEB2), (WEB3), (WEB4).

Çalışmanın ileriki bölümlerinde hizmet ve hizmet kalitesi kavramları üzerinde durulacak, araştırmaya konu olan düşük maliyetli havayolu iş modeli açıklanmaya çalışılarak, araştırmanın bir bölümünü ilgilendiren kabin ekipleri hakkında bilgiler yer alacaklardır. Yolcu ve kabin ekiplerinin karşılaştırmalı analizlerine yer verilecek ve sonuç bölümünde elde edilen bulgular yorumlanacaktr.

Çalışmada yolcularla en fazla vakit geçiren havayolu personeli olan kabin görevlileri ile yolcuların kabin hizmetleri kalite algılarının karşılaştııımalı değerlendirilmesi amaçlanmıştır. Literatürde dış müşteriler ile yapılan çok sayıda hizmet kalitesi ile ilgili çalışma bulunmaktadır. Bununla birlikte az sayıda da iç müşteriler ile yapılan çalışmalar bulunaktadır. Bu çalışmanın amacı hizmet kalitesinin kabin içi hizmetlere indirgeyerek düşük maliyetli bir havayolu işletmesinin hizmet kalitesi performansının iç ve dış müşteriler açısından değerlendirmesidir. 


\section{HIZMET KAVRAMI VE TANIMI}

İnsan ihtiyaçlarının hepsi elle tutulur, gözle görülür cinsten değildir. Turizm, tedavi, saç kesimi birer hizmet olarak kabul edilir (Aktepe, 2016: 20). Bununla beraber ürün içerisindeki ağılıkları farklı olmakla birlikte fiziksel ürünlerin içinde hizmetler, hizmetlerin içerisinde fiziksel ürünler yer alabilmektedir (Süer, 2014; 194). Hizmet sunumu, ürün öğelerinin bir araya getirilme ve müşteriye teslim edilme süreci olarak kavramsallaştrılabilir (Page, 2016: 318). Hizmet; bireylerin ya da bireylerden oluşan grupların, gereksinimlerini gidermek amacıyla, belirli bir fiyattan satışa sunulan ve herhangi bir malın mülkiyetine sahip olmayı gerektirmeyen, yarar ve doyum sağlayan, soyut faaliyetlerdir (Zengin ve Erdal, 2000: 44). Başka bir tanıma göre hizmet; birey veya örgüt tarafindan başka birey veya örgütlere yarar sağlayan faaliyetlerdir (Altan ve Atan, 2004: 19). Süer (2014: 200)'e göre hizmet; tüketicilerin ihtiyaçlarını gideren, fiziksel bir ürüne bağlı olarak veya bağlı olmadan yapılan işletme faaliyetleridir.

Tanımlar incelendiğinde, hizmet kavramının soyutluk özelliğine değinilmiştir. Ayrıca hizmetlerin hizmeti alana bir fayda sağlaması gerekmektedir. Bununla birlikte hizmet alan ve hizmet verenden (tekil veya çoğul) oluşan iki tarafin da olması gerekmektedir. Süer (2014: 200), hizmetlerin fiziksel bir ürüne bağlı olarak veya bağlı olmadan yapılabileceğini ifade etmektedir. Bu bağlamda, "hizmet; birey veya örgütün başka birey veya örgüt yararına yaptığı, fiziksel ürünler ile birlikte veya bağımsız olarak sunulan ve muhatabına doyum sağlayan ticari veya ticari olmayan faaliyetlerdir olarak tanımlanabilir."

Hizmetleri, fiziksel ürünlerden farklı kılan bazı özellikler bulunmaktadır. Bunlar; soyutluk, heterojenlik, eşzamanlılık, stok edilemezliktir (Altunışık ve Karataş, 2015: 546).

Soyutluk: Hizmetlerin duyu organları ile algılanması zordur. Fiziksel ürünlerdeki gibi hizmetler, tadılamaz, koklanamaz, işitilemez ve görülemezler. Hizmetler ancak deneyim ile algılanabilir. Örneğin uçak ile yapılacak bir yolculuktan önce seyahatin ne derece tatminkâr ve güvenli olacağına dair somut bir garanti yoktur (Altunışık, 2009: 29).

Hetorejenlik: Hizmetler; hizmeti kimin yaptı̆̆ı, kimin aldığı, yeri ve zamanına göre farklııık gösterir. Alınan hizmet bu değişkenlere bağlı olarak bir dahaki sefere daha farklı alınacaktrr. Bu sebeple hizmetler değişken yani heterojendir (Kotler, 2014: 41).

Eşzamanlılık: Fiziksel ürünler üretilir ve depolanır. Daha sonraki aşamada aracı kuruluşlar ile dağıtımı gerçekleşir ve sonunda satılır. Hizmetlerde ise üretim ve tüketim aynı anda gerçekleşmektedir. Yani birbirlerinden ayrılamazlar (Süer, 2014: 200).

Stok Edilemezlik: Hizmetler daha sonra kullanılmak üzere stoklanamazlar. Gün içerisinde boş kalan restoran masalarının, boş uçak koltuklarının veya satılamayan sinema bileti veya kayak parkurunun daha sonra satılmak üzere stoklanması mümkün değildir (Altunışık, 2009: 32).

Hizmetleri fiziksel ürünlerden ayıran özellikler incelendiğinde soyutluk özelliği ve insan doğasına bağlı olarak standartlaşmanın zorlukları öncelikle göze çarpmaktadır. Üretim ve tüketimin eşzamanlı gerçekleşmesi sebebiyle yapılan hataları telafi etmek oldukça zor olabilmektedir. Bununla birlikte, stok edilemezlik özelliğinden dolayı geri döndürülemeyen gelir kayıpları oluşabilmektedir. 


\section{HIZMET KALITESI KAVRAMI VE TANIMI}

Hizmet kalitesini iyi kavrayabilmek için memnuniyet, kalite ve değer kavramlarını iyi anlamak gereklidir. Bu kavramlar hizmeti alan kişilerce soyut olarak nitelendirilse de gelecekteki satın alma davranışlarının biçimlenmesinde önemli rol oynamaktadırlar (Rust ve Oliver, 1994: 3). Kalitenin tanımı hem kişiden kişiye hem de durumdan duruma değişebilmektedir (Brown ve diğerleri, 1991: 1). Kalitenin literatürde kesin bir tanımı olmamakla birlikte, bakış açısına göre ise bazı tanımlamalara yer verilmektedir. Ürün tabanlı yaklaşıma göre kalite, bir ürünün özelliklerinin miktarından ve ürünün içeriğinden anlaşılmaktadır. Üretim tabanlı yaklaşıma göre kalite, bir ürünün uygun üretim özellikleri ve hizmet standartlarında olmasıdır (Zeithaml, 1988: 4). Japon felsefesine göre kalite; müşteriye doğru şeyi, doğru zamanda vermektir (Frayman, 2002: 4). Başka bir tanıma göre müşteri ihtiyaç ve isteklerini karşılama düzeyi veya daha basit tanımıyla hizmetin veya ürünün kullanım amacına uygunluğu olarak tanımlanabilir (Jain, 2001: 1).

Bir ürün tüketici tarafindan kaliteli olarak değerlendiriliyorsa o ürün kalitelidir ve bu değerlendirmede her zaman ürünün teknik özellikleri göz önünde bulundurulmamaktadır. Bu kalitenin tüketici açısından ifade ediliş şeklidir (Schineider ve White, 2004: 10). Hizmet kalitesi değerlendirilirken, müşterilerin kaliteyi değerlendirebileceği birkaç limitli fiziksel kanıt bulunmaktadır (Restoranın mimarisi, bardakların kalitesi vb.). Bu limitli fiziksel kanıtlarla beraber birçok fiziksel olmayan kanıtlar kalite değerlendirmesi içinde yer alır (Parasuraman ve diğerleri, 1985: 42). Genel bir tanım yapmak gerekir ise; hizmet kalitesi, müşteri istek ve intiyaçlarının olabilecek en iyi şekilde karşılanması olarak tanımlanabilir (Koçoğlu ve Aksoy, 2012: 2).

Hizmet kalitesi ile ilgili ilk model 1984 yılında Grönross tarafindan geliştirilmiş olan hizmet kalitesi modelidir. Grönross'a göre hizmet kalitesinin iki bileşeni teknik ve fonksiyonel kalitedir. Teknik kaliteye, satın alınan hizmetin nihai amacına yöneliktir. Restoranda gelen yemek, uçak ile yapılan yolculuk, otelde yapılan konaklama gibi örnekler verilebilir.

Fonksiyonel kalite ise hizmetin alınış şekli ile ilgilidir. Restoranda yemeği sunarken garsonun davranışları, kılık kıyafetleri, ne ve nasıl konuştukları ile alakalıdır (Grönross, 1984: 38).

Hizmet kalitesiyle ilgili değerlendirmelerde genellikle hizmetlerin soyut özelliğinden dolayı hizmet kalitesinin tanımlanmasında güçlüklerin olduğu konusuna değinilmektedir. Herkes tarafindan kabul edilen kesin bir tanımın olmama sebebi ise kalitenin herkes tarafindan farklı algılanması olabilir. Tüketicilerin temel intiyaçları benzer olsa da ürünün veya hizmetin detaylarında farklı beklentiler içerisinde olabilmektedirler. Bu bağlamda, sunulan ürün ve hizmetlerin, tüketicilerin temel ihtiyaçlarını giderebilme becerisiyle birlikte, tüketicilerin özellikli beklentilerini karşılayabilme yetisinin kalite algısında belirleyici olduğu söylenebilir. Parasuraman ve diğerleri, (1985), hizmet kalitesini 10 boyutta değerlendirmektedir. Bu boyutlar;

Güvenilirlik: Hizmetin belirlenen zamanda yapılması, doğru faturalandırma ve kayıtların doğru tutulmasını ifade etmektedir.

Sorumluluk: Çalışanların hizmet verirken gönüllülükleri ve süratli şekilde çalışmaları şeklinde değerlendirilmektedir.

Yetkinlik: Çalışanların hizmet verdikleri alana olan hâkimiyeti ve ürün bilgisini ifade etmektedir. 
Nezaket: Çalışanların hizmet verdikleri sırada müşterilere gösterdikleri saygı, ilgi ve samimiyeti ifade etmektedir

Erişilebilirlik: Hizmetlere ve hizmet verenlere kolay ulaşılabilirliği ifade etmektedir.

İletişim: Müşterilerin anlayabilecekleri dilden konuşmayı ve onları dinlemeyi ifade etmektedir.

Kredibilite: Müşterilerin marka üzerindeki olumlu izlenimlerini ifade etmektedir.

Güvenlik: Fiziksel sağlığı, finansal güveni ve kişisel bilgilerin saklı kalmasını ifade eder.

Müşteriyi Anlamak: Müşteri istek ve ihtiyaçlarını anlamak için gerekli çabayı göstermeyi ifade etmektedir.

Somutluk: Hizmet sunulurken kullanılan fiziksel araçlardaki kaliteyi ifade eder.

Hizmet kalitesini değerlendirdiğine inanılan bu 10 boyut Parasuraman ve diğerleri, (1988) tarafindan fiziksel özellikler, güvenilirlik, sorumluluk, güven ve empati olarak 5 boyuta indirgenmiştir. Parasuraman ve arkadaşlarına göre hizmet kalitesi, beklenti ile algılanan kalite arasındaki fark ölçülerek bulunabilmektedir ve bu farklara boşluk adı verilen skorlar verilmektedir. Algı skoru beklenti skorundan çıkarıldığında çıkan skor pozitif olarak ne kadar yüksekse, müşteri beklentilerinin karşılandığı ve hizmet kalite algısının yüksek olduğu sonucuna varılır. Eğer sonuç negatif ise, müşteri beklentileri karşılanamamaktadır şeklinde yorumlanmaktadır ve bu modele Servqual adı verilmiştir.

Cronin ve Taylor, (1992: 64) ise hizmet kalitesi algısının beklenti ile ölçülmesinin doğru olmayacağını, önemli olanın ve ölçülmesi gerekenin performans olduğunu öne sürerek Servqual ölçeği ile aynı soru ve boyutlardan oluşan fakat beklenti ölçmeyen, sadece müşteri algılarını dikkate alan performans odaklı Servperf ölçeğini geliştirmişlerdir. Servperf ölçeğinin temel prensibi, katılımcıların performans skorlarını verirken, beklentilerini göz önünde bulundurmalarıdır.

\section{HAVAYOLU TAŞıMACILIĞI VE DÜŞÜK MALIYETLI HAVAYOLLARI}

Sivil havacılık faaliyetleri, ülkelerin ekonomik ve sosyal kalkınmasında önemli bir rol oynamaktadır (Ömürbek ve Kınay, 2013: 343). Son yıllarda küreselleşmenin etkisiyle beraber iş ve turistik amaçlı yapılan seyahatlerin sayısı artmış ve yolcuların demografik özellikleri değişmiştir (Okumuş ve Asil, 2007: 7). Bu değişimle beraber yolcular genellikle daha üst düzeyde hizmet kalitesi beklentisi içerisine girmişlerdir. Havayolları, işletme masraflarını düşürmek ile birlikte müşteri istek ve intiyaçlarını da dikkate almak zorunda kalmışlardır (Page, 2016: 166). 2017 Yılı itibariyle dünyada uluslararası seyahatlere katılan insan sayısı 1,2 milyarı aşmış bulunmaktadır. Gelecekte de bu artışın sürmesi söz konusudur. İnsanların uluslararası seyahatlerinde her geçen gün artan oranda havayollarını kullanmaları, havayolu taşımacılı̆ıının turizm açısından gelecekte de önemini koruyacağını göstermektedir (Zengin vd., 2017: 25). Turistik taşımacılıkta sezona bağlı olarak genellikle kiralık (charter) uçaklar ile düşük maliyetli (low-cost) sefer düzenleyen havayolu firmaları tercih edilmektedir.

Düşük maliyetli havayolları ise geleneksel havayollarından farklı bir model sunarlar. Temel amaç operasyon maliyetlerini en düşük seviyeye çekerek, mümkün olan en düşük fiyattan bilet satmak, böylelikle rekabet gücü ve kar elde etmektir. Düşük maliyetli havayollarının genel bir tanımı olmamakla beraber sundukları hizmetler farklılık gösterebil- 
mektedir (Gillen ve Morisson, 2003: 16; Gillen ve Lall, 2004: 48; Chiou ve diğerleri 2010: 228; Belobaba ve diğerleri, 2016: 140), South West Havayolları'nın önderliğini yaptığı düşük maliyetli havayolu modelini Ryan Air bir adım daha öne taşıyarak uçakta sunulan ikramları ücretli olarak müşterilerine sunmuş, sadakat programı, aracı seyahat acenteleri gibi ek maliyet getirecek uygulamalardan kaçınmıştır (Gillen ve Lall, 2004: 47). Düşük maliyetli havayolları genellikle ikincil havalimanlarına operasyonlar gerçekleştirir ve teşvikler geliştirerek pazarı hareketlendirirler (Page, 2016: 169).

Türkiye'ye düşük maliyetli havayolu taşımacılığı ilk olarak 2005 yılında Pegasus Havayolları tarafindan başlatılan bir iş modeli olup, günümüzde Onur Havayolları, Sun Express ve Anadolu Jet diğer düşük maliyetli havayolu işletmeleri olarak faaaliyetlerini sürdürmektedir.

\section{KABIN EKIBI KAVRAMI}

Sivil Havacılık Genel Müdürlüğü (SHGM)'nin tanımına göre; “yolcu taşımacılığı yapan hava araçlarında gerekli emniyet ve güvenlik önlemlerinin uygulanmasından ve yolcu konforundan sorumlu görevliler "kabin memuru" ya da "kabin görevlisi" olarak tanımlanmaktadır (WEB5). Kabin ekipleri ile ilgili tanımlar genelde emniyet ile ilgilidir. Akademik yazında ise genellikle hizmet görevleri üzerine çalışmalar yapılmıştır. Çalıştıkları havayolu işletmesi düşük maliyetli bir havayolu olsa da kabin ekiplerinin birinci öncelikleri uçuş emniyetinin sağlanmasıdır (Rhoden ve diğerleri, 2008: 538). Uçuş emniyetinden sonraki görevleri, işletme izlenceleri çerçevesinde en üst düzeyde yolcu konforunun sağlanması olduğu söylenebilir. Türkiye'de kabin memuru olabilmek için mevzuata göre aranan asgari gereklilikler aşağıda yer almaktadır (WEB6):

- En az 18 yaşında olmak

- Sağlık yönünden görevini yerine getirmeye uygun olduğunun kontrol edilmesi amacıyla genel müdürlük tarafindan yetkilendirilmiş bir sağlık kuruluşunun düzenli araIıklarla muayenesinden veya değerlendirmesinden geçmiş olmak,

- Işsletme el kitabı içerisinde belirtilen usullere uygun olarak görevlerini yerine getirilebilecek yeterlilikte olmak (Boy, kilo, psikolojik test vb.),

- Yurt içi veya yurt dışında asgari 10 yıllık eğitim veren lise veya benzeri okul mezunu olmak,

- Ingilizce bilmek. (Detaylar havayolu işletmesinin iç prosedürü ile belirlenir).

\section{ARAŞTIRMANIN METODOLOJISI}

\subsection{Araştırmanın Amacı ve Önemi}

Çalışmanın amacı; iç ve dış müşterilerin hizmet kalitesi algıları ölçülmeye çalışılarak, kabin ekibi ve yolcuların kabin hizmetlerine ilişkin kalite algılarını karşılaştırmalı olarak ortaya ortaya çıkarmakttr. Böylelikle iç ve dış müşterilerin söz konusu işletme için sunulan kabin içi hizmetler bağlamında olası algı farklılıkları çalışma kapsamında ortaya çıkarılması hedeflenmiştir. Çalışma düşük maliyetli bir havayolu işletmesinde kabin hizmetlerine yönelik hizmet kalitesini işgören ve yolcular açısından karşılaştırmalı olarak değerlendirmeye çalışan ilk araştırmadır. Böylelikle hem işletmenin hizmet kalitesi performansı hem de işgören ve yolcular arasındaki algı farklılıklarının ortaya konulması amaçlanmıştir. 


\subsection{Araştırmanın Yöntemi ve Kısıtları}

Bu çalışma, nicel bir araştırma olarak tasarlanmıştır. Veri toplama aracı olarak anket tekniğinden, verilerin analizinde ise SPSS istatiksel analiz programından yararlanılmıştır. Paket programda güvenilirlik analizi, faktör analizi, frekans analizi, Kruskal Wallis testi, Mann Whitney U testi, bağımsız iki değişkenli t testi, tek yönlü Anova testleri uygulanmış ve elde edilen bulgular tablolar halinde sunulmuştur.

Araştırma Türkiye'de faaliyet gösteren düşük maliyetli tek bir havayolunun yolcuları ve kabin ekipleri ile yapılmıştr. Bu sebeple diğer faaliyette bulunan düşük maliyetli ve geleneksel havayolları için genelleme yapılamamaktadır. Yolcu anketlerinde katılımcılara hangi havayolunu tercih ettikleri sorulmuş ve $X$ havayolu işletmesini, tercih edenlerin verileri çalışma kapsamında değerlendirmeye alınmıştı. Bununla birlikte yolcular için yapılan araştırma sadece Türk yolcular ile yapılmıştır. Bu sebeple diğer milliyetlerden yolcuların hizmet kalitesi algısı ile ilgili bir sonuç bu çalışmadan çıkarılamamaktadır. Ayrıca kabin ekipleri ile yapılan çalışmada kullanılan örneklem sayısı 264'tür. Coşkun ve diğerlerine (2015: 137) göre \%5 belirlilik düzeyinde 1400 kişilik bir evrende 302 katılımcının verileri gerekmektedir. Bu anlamda araştırmanın kabin ekipleri ile yapılan bölümünün evreni temsil gücü düşük olabilir.

\subsection{Araştırmanın Evren ve Örneklemi}

Araştırmanın evrenini $X$ havayolu işletmesi ile uçuş tecrübesi yaşamış yolcular ve bu işletmede çalışan kabin personeli oluşturmaktadır. X havayolu 2016 yılında iç ve dış hatlarda 24,14 milyon yolcu taşımıştır. Bunun 15,29 milyonu iç hatlarda 8,59 milyonu dış hat uçuşlarında taşınmıştır. Fakat bu sayıya çoğul uçuşlar dahildir. Yani bir kişinin birden çok kez yaptığı uçuşlar farklı yolcu hizmet almış gibi sayılmıştır. Uçuş gerçekleştiren münferit yolcu sayısına ilişkin bir bilgi elde edilmemiştir. Ayrıca bu yolcularının kaçının Türk olduğu da tespit edilememiştir. Bu sebeple araşttrmanın evreni kesin olarak tespit edilememektedir. Bundan dolayı yolcular için $\% 95$ güvenilirlik düzeyinde 384 veri istatiksel olarak geçerliliği sağlamaktadır (Gürbüz ve Şahin, 2017: 130). Araştırmanın yapıldığı dönemde işletmede 1400 kabin personeli bulunmaktadır. Anketler yolcular için online ve basılı olarak 02 Mart-19 Nisan 2017 tarihleri arasında dağıtılmış ve sonuçlar kabul edilmiştir. Online anketler için sosyal medya ve forum siteleri kullanılmıştr. Kısaca yolcu anketleri için kolayda ve kartopu örnekleme yöntemleri birlikte kullanılarak veriler elde edilmiştir. Sonuç olarak online 415 anketten ve basılı 64 anketten geri dönüş sağlanmıştır. 23 anket eksik ve hatalı veriler nedeniyle değerlendirilmeden çıkarılmış ve nihai olarak analizler için 456 anket formu değerlendirmeye alınmıştır. Kabin ekiplerinin anketleri ise; basılı olarak 01 Ocak- 10 Mart tarihleri arasında ekiplerin bekleme odasında ve uçuş görevleri sırasında doldurtulmuştur. Örneklem oluşturmada kolayda örnekleme tekniği seçilmiştir. Online anketler aynı tarihlerde kabin ekiplerinin e-mail adreslerine gönderilmiştir. Online olarak 62, basılı olarak 202 anket elde edilmiş ve elde edilen 264 anketin tamamı kullanılmıştır. Kabin memurları/amirleri için elde edilen örneklem sayısı evrenin $\% 18,85$ 'ini oluşturmaktadır.

\subsection{Anket FormununDizaynı}

Havayolu işletmelerinde yapılan hizmet kalitesi ölçüm çalışmalarında Servperf ölçeğinin yeterliliğine yönelik çalışmalar bulunmuştur (Yıldız ve Erdil 2013: 89; Jain ve diğer- 
leri, 2004: 34; Bülbül ve Demirer, 2008: 194) anket formu 22 maddeden oluşmaktadır. Parasuraman ve diğerleri, (1988) tarafindan geliştirilen Servqual hizmet kalitesi ölçeği ile aynı önermeleri kullanan, Cronin ve Taylor (1992) performans odaklı Servperf ölçeği kullanılarak hazırlanmıştır. Yani ölçekte sadece algı sorularına yer verilmektedir. Beklenti soruları ölçeğe dahil edilmemiştir. Ölçeğin Türkçe önermeleri daha önce Servqual/Servperf ölçeği ile çalışma yapılmış makalelerden alınmış ve kabin içi hizmetlere uyarlanarak anket tasarlanmıştır. Hizmet kalitesinin boyutları, boyutları ölçtüğü düşünülen soru adedi ve önermelerin alındığı yayınlar aşağıda belirtilmiştir.

Madde 1, 2, 3, 4

: Fiziksel özellikler (Yıldız ve Erdil, 2013: 93)

Madde 5, 6, 7, 8, 9

: Güven (Okumuş ve Asil, 2007: 164)

Madde 10, 11, 12, 13

: Heveslilik (Okumuş ve Asil, 2007: 164)

Madde 14, 15, 16, 17

: Güvenilirlik (Pekkaya ve Akıllı, 2013: 85)

Madde 18, 19, 20, 21, 22 : Empati (ibik, 2006: 72)

Ölçek, Parasuraman ve diğerleri, (1988), Pekkaya ve Akıllı, (2013: 90) ve Jain ve diğerlerinin, (2004: 35) çalışmalarında sunduğu öneriler esas alınarak 7’li Likert ölçeği kullanılarak hazırlanmıştır. Çalışmada (Parasuraman, Zeithmal, \& Berry, 1988, s. 38) ve (Cronin \& Taylor, 1992, s. 65)'deki ile aynı ölçek kullanılarak "1" kesinlikle katılmıyorum ve "7" kesinlikle katılıyorum ifadesi ile seçenekler anlamlandırımış, 2,3,4,5,6 seçeneklerine ise herhangi bir ifade ataması yapılmamıştı. Servperf/Servqual orijinal ölçekte ağırlıklandırma kullanılmıştır. Fakat bu çalışmada online anketlerde çok sayıda hatalı veri girişi (boyutlara verilen rakamsal değerlerinin toplamının 100 etmemesi veya buraya farklı ifadeler yazılması) nedeniyle ağırlıklandırma yapılamamıştır. Ağırlıksız olarak kullanıldığında bu ölçek aritmetik ortalamaların alınması ile performans skorları elde edilmektedir (Koçoğlu \& Aksoy, 2012, s. 13), (Pekkaya \& Akıllı, 2013, s. 84). Araşttrmada kullanılan anketin önermeleri aşağıda gösterilmiştir. İç müşterilere çalıştı̆̆ım havayolu, dış müşterilere tercih ettiğim havayolu kelimeleri ile başlayan aşağıdaki önermeler aşağıda tabloda gösterilmiştir.

\section{Tablo 1: Anket Formunda Yer Alan Önermeler}

1. Modern görünüşlü uçaklara sahiptir.

2. Fiziksel araçları çekicidir. (Kabin içi, dergi)

3. Kabin ekipleri temiz ve düzgün görünüşlüdür.

4. Uçuş esnasında sunduğu ikram malzemeleri kalitelidir.

5. Hizmetleri taahhüt ettiği zamanda yerine getirir.

6. Hizmetleri taahhüt ettiği şekilde yerine getirir.

7. Güvenilir bir havayoludur.

8. Yolcu ve hizmet kayıtlarını düzgün bir şekilde tutar.

9. Yolcularına hatasız hizmet sunmak için sürekli çalışır.

10. Kabin ekipleri yolcu hizmetlerini hızlı bir şekilde karşılamaktadır.

11. Kabin ekipleri yolcu sorularına tatmin edici cevaplar verirler.

12. Kabin ekipleri yolculara yardım etme konusunda isteklidir. 
13. Kabin ekipleri hiçbir zaman yolcuların isteklerini yerine getiremeyecek kadar meşgul değillerdir.

14. Yolcular kabin ekiplerine güvenir.

15. Yolcular kabin ekipleriyle yapılan ödeme işlemlerinde kendilerini güvende hissederler.

16. Kabin ekipleri yolculara karşı naziktir.

17. Kabin ekipleri yolcuların sorularına cevap verebilecek bilgiye sahiptir.

18. Kabin ekipleri yolcuların kişisel intiyaçlarını anlar.

19. Kabin ekipleri yolculara bireysel ilgi gösterir.

20. Kabin ekipleri yolcuların menfaatlerini kendi menfaatleri gibi düşünür.

21. Kabin ekipleri servise başlama zamanını yolcuların intiyaçlarına göre ayarlamaktadır.

22. Kabin ekipleri yolcuların kişisel isteklerine karşı anlayışlıdır.

18. Kabin ekipleri yolcuların kişisel ihtiyaçlarını anlar.

19. Kabin ekipleri yolculara bireysel ilgi gösterir.

20. Kabin ekipleri yolcuların menfaatlerini kendi menfaatleri gibi düşünür.

21. Kabin ekipleri servise başlama zamanını yolcuların ihtiyaçlarına göre ayarlamaktadır.

22. Kabin ekipleri yolcuların kişisel isteklerine karşı anlayışlıdır.

\section{Araştırmanın Hipotezleri}

H1: Kabin ekipleri ile yolcuların hizmet kalitesi algıları arasında anlamlı farklılık vardır. H2: Yolcuların hizmet kalitesi algıları eğitim düzeylerine göre farklılık göstermektedir

H3: Kabin ekiplerinin hizmet kalitesi algıları eğitim düzeylerine göre farklılık göstermektedir.

\subsection{Araştırma Bulguları ve Yorumlanması}

\subsubsection{Hizmet Kalitesinin Boyutlarına Göre Cronbach's Alpha Değerleri}

Kabin ekibi ölçeğinin Cronbach's Alpha iç tutarlılık sayısı 0,940, yolcu ölçeğinin Cronbach's Alpha iç tutarlılık sayısı 0,938'dir. Hizmet kalitesinin alt boyutlarına göre Cronbach's Alpha değerleri, kabin ekibi için Tablo 2, yolcular için Tablo 3'de verilmiştir. Ölçeğin içsel tutarlılı̆ının ölçülmesinde en çok kullanılan yöntemlerden biri Cronbach's Alpha sayısıdır ve bu sayının sosyal bilimlerde en az 0,70 olması tercih edilir (Coşkun ve diğerleri, 2015: 125). Buna göre her iki ölçeğin de yüksek derecede güvenilir olduğu söylenebilir.

Tablo 2: Hizmet Kalitesinin Boyutlarına Göre Cronbach's Alpha Değerleri (Ekip)

\begin{tabular}{ll} 
Hizmet Kalitesi Boyutları & Cronbach's Alpha Değeri \\
\hline Fiziksel Özellikler & 0,701 \\
Güven & 0,879 \\
Heveslilik & 0,766 \\
Güvenilirlik & 0,801 \\
Empati & 0,874
\end{tabular}


Tablo 3: Hizmet Kalitesinin Boyutlarına Göre Cronbach's Alpha Değerleri (Yolcu)

$\begin{array}{ll}\text { Hizmet Kalitesi Boyutları } & \text { Cronbach's Alpha Değeri } \\ \text { Fiziksel Özellikler } & 0,719 \\ \text { Güven } & 0,877 \\ \text { Heveslilik } & 0,875 \\ \text { Güvenilirlik } & 0,870 \\ \text { Empati } & 0,863\end{array}$

\subsubsection{Faktör Analizi Sonuçları (Yolcular)}

Aşağıda tabloda kullanılan ölçeğe ilişkin faktör analizi yer almaktadır. Yapılan analizde KMO değeri 0,937, Barlett Test değeri ise 6279,668 bulunmuştur. KMO değeri 0,90 ile 1,00 arasında bulunması faktör analizi için örneklem yeterliliğinin çok iyi olduğu anlamına gelmektedir (Alpar, 2017: 268). KMO değeri ve Barlett Testi'nin anlamlı çıkması ölçeğin faktör analizi için uygun olduğu anlamına gelmekted. Faktörler arası korelasyonun varlı̆̆ından dolayı rotasyon için Direct Oblimin yöntemi kullanılmıştır. Analiz yapılırken faktör analizi kullanılan kalite ölçeğinin her ne kadar farklı boyutları olsa da faktörler arasında yüksek korelasyonun olması ve faktörlerdeki alt boyutların katlımcılar tarafindan farklı faktörlerde algılanabilmesi sebebiyle Parasuraman ve diğerlerinin, (1991) ölçeği geliştirirken yaptığı faktör analizi ile benzer sonuçlar ortaya çıkmış ve bazı maddelerin farklı boyutlarda yer almasına neden olmuştur. Katılımcılar, "kabin ekipleri temiz ve düzgün görünüşlüdür" önermesi heveslilik boyutu altında düşünmüş olsalar da bunun fiziksel bir özellik olduğu gerçeği ile bo soruya müdahale edilmemiştir. İki faktöre dağılan 4. önerme (Uçuş esnasında sunduğu ikram malzemeleri kalitelidir.) ile 18. önerme (Kabin ekipleri yolcuların kişisel ihtiyaçlarını anlar.) veri setinden çıkarılmıştır.

Tablo 4: Dış Müşterileri (yolcular) Verilerine Yönelik Faktör Analizi

\begin{tabular}{|c|c|c|c|c|}
\hline \multicolumn{5}{|c|}{ Fiziksel Özellikler } \\
\hline S1 & & & & 0,859 \\
\hline S2 & & & & 0,811 \\
\hline S3 & 0,533 & & & 0,409 \\
\hline S4 & & 0,501 & & 0,398 \\
\hline \multicolumn{5}{|l|}{ Güven } \\
\hline S5 & & 0,885 & & \\
\hline S6 & & 0,804 & & \\
\hline S7 & & 0,579 & & \\
\hline S8 & & 0,569 & & \\
\hline S9 & & 0,752 & & \\
\hline \multicolumn{5}{|l|}{ Heveslilik } \\
\hline S10 & 0,573 & & & \\
\hline
\end{tabular}




\begin{tabular}{|c|c|c|}
\hline S11 & 0,544 & \\
\hline S12 & 0,680 & \\
\hline S13 & 0,688 & \\
\hline \multicolumn{3}{|c|}{ Güvenilirlik } \\
\hline S14 & 0,689 & \\
\hline S15 & 0,715 & \\
\hline S16 & 0,862 & \\
\hline S17 & 0,833 & \\
\hline \multicolumn{3}{|c|}{ Empati } \\
\hline S18 & 0,460 & 0,505 \\
\hline S19 & & 0,816 \\
\hline S20 & & 0,745 \\
\hline S21 & & 0,761 \\
\hline S22 & & 0,558 \\
\hline \multicolumn{3}{|c|}{ N:526, KMO: 0,937 } \\
\hline \multicolumn{3}{|c|}{ Bartlett's Sph X²: 6279,668; p: 0,000 } \\
\hline \multicolumn{3}{|c|}{ Açılanan Toplam Varyans: \%66,743 Eigenvalue: 1} \\
\hline
\end{tabular}

Aşağıda tabloda hizmet kalitesi ölçek boyutlarının birbirleri ile korelasyonu görülmektedir. Söz konusu beş boyut birbirleri ile orta ve yüksek düzeyde korelasyona sahiptir. Özellikle heveslilik ve güvenilirlik boyutlarının 0,785 gibi yüksek bir korelasyona sahiptir.

Tablo 5: Hizmet Kalitesi Faktörlerinin Birbirleri ile Korelasyonu (yolcu verileri)

$\begin{array}{llllll}\text { Değişkenler } & \text { Fiziksel Özellikler } & \text { Güven } & \text { Heveslilik } & \text { Güvenilirlik } & \text { Empati } \\ \text { Fiziksel Özellikler } & 1 & & & & \\ \text { Güven } & 0,487^{*} & 1 & & & \\ \text { Heveslilik } & 0,501^{*} & 0,640^{*} & 1 & & \\ \text { Güvenilirlik } & 0,442^{*} & 0,564^{*} & 0,785^{*} & 1 & \\ \text { Empati } & 0,422^{*} & 0,517^{*} & 0,637^{*} & 0,578^{*} & 1 \\ * p<0,01 & & & & & \end{array}$




\subsubsection{Katılımcıların Demografik Özelliklerine Göre Frekans Analizi (Ekip)}

Katılımcıların cinsiyetleri, yaşları, medeni durumları ve eğitim durumlarını gösteren frekans analizi Tablo 6'da gösterilmiştir. Katlımcıların büyük çoğunluğu 95 kişiyle ön lisans ve 138 kişiyle lisans mezunlarından oluşmaktadır. Lise mezunu 28 kişi çalışmaya katılım sağlamış olup lisansüstü mezunu sadece 3 kişi bulunmaktadır. Katılımcıların büyük çoğunluğu 230 kişiyle 35 yaş altı olup, 35 yaş üstü sadece 34 kişi kathlım göstermiştir.

Tablo 6: Katılımcıların Demografik Özelliklerine Göre Frekans Analizi (Ekip)

$\begin{array}{llll} & & \text { Frekans }(\mathbf{n}) & \text { Yüzde }(\%) \\ \text { Cinsiyet } & \text { Kadın } & 154 & 58,3 \\ & \text { Erkek } & 110 & 41,7 \\ \text { Yaş } & 20-24 & 63 & 23,9 \\ & 25-29 & 111 & 42,0 \\ \text { Medeni Durum } & 30-34 & 56 & 21,2 \\ & 35 \text { ve üstü } & 34 & 12,9 \\ & \text { Evli } & 53 & 20,1 \\ \text { Eğitim Durumu } & \text { Bekâr } & 211 & 79,9 \\ & \text { Lise } & 28 & 10,6 \\ & \text { Ön lisans } & 95 & 36,0 \\ & \text { Lisans } & 138 & 52,3 \\ & \text { Lisansüstü } & 3 & 1,1\end{array}$

\subsubsection{Katılımcıların Demografik Özelliklerine Göre Frekans Analizi (Yolcu)}

Çalışmaya $X$ havayolu ile en az bir uçuş tecrübesi yaşamış 456 kişi kathlım göstermiştir. Katılımcılar ağırlıklı olarak lise ve lisans mezunlarından oluşmaktadır. Katılımcıların yaşları, kabin ekiplerine benzer şekilde 35 yaş altı katılımcılardan oluşmaktadır. Katılımcıların \%80,2'si havayolunu kullanarak yılda birden fazla seyahat gerçekleştirmektedir.

Tablo 7: Katılımcıların Demografik Özelliklerine Göre Frekans Analizi (Yolcu)

$\begin{array}{llll} & & \text { Frekans }(\mathrm{n}) & \text { Yüzde }(\%) \\ \text { Cinsiyet } & \text { Kadın } & 103 & 22,6 \\ & \text { Erkek } & 353 & 77,4 \\ & 0-19 & 49 & 10,7 \\ & 20-24 & 183 & 40,1 \\ \text { Yaş } & 25-29 & 106 & 23,2 \\ & 30-34 & 67 & 14,7 \\ & 35 \text { ve üstü } & 51 & 11,2\end{array}$




$\begin{array}{llll}\text { Medeni Durum } & \text { Evli } & 117 & 25,7 \\ & \text { Bekâr } & 339 & 74,3 \\ & \text { ilköğretim } & 4 & 0,9 \\ & \text { Lise } & 136 & 29,8 \\ \text { Eğitim Durumu } & \text { Ön lisans } & 38 & 8,3 \\ & \text { Lisans } & 219 & 48,0 \\ & \text { Lisans Üstü } & 59 & 13,0 \\ & \text { 0-1500 } & 154 & 33,1 \\ \text { Gelir Düzeyi } & 1501-2500 & 96 & 20,6 \\ & \text { 2501-3500 } & 98 & 21,1 \\ & \text { 3501-4500 } & 49 & 10,5 \\ & \text { 4501 ve üstü } & 68 & 14,6 \\ \text { Seyahat Sıklığı } & \text { Ayda bir } & 116 & 24,9 \\ & \text { Üç ayda bir Altı } & 141 & 30,3 \\ & \text { ayda bir } & 116 & 24,9 \\ & \text { Yılda bir } & 92 & 19,8\end{array}$

\subsubsection{Kabin Ekiplerinin ve Yolcuların Hizmet Kalitesi Algılarına ilişkin Frekans} Analizi

Tabloda kabin ekipleri ve yolculardan oluşan katlımcıların 22 önermeden oluşan ölçeğe verdikleri cevapların ortalamaları karşılaştırılmıştır. Genel olarak kabin ekiplerinin verilen hizmetlere ilişkin kalite algı skorları müşterilerin kalite algılarından daha yüksek olduğu görülmektedir.

Tablo 8: Kabin Ekiplerinin ve Yolcuların Hizmet Kalitesi Algılarına Illişkin Frekans Analizi

\begin{tabular}{|c|c|c|c|c|c|c|c|}
\hline \multirow[b]{2}{*}{$\begin{array}{l}\text { Soru } \\
\text { Önermesi }\end{array}$} & \multicolumn{3}{|c|}{ KABINN EKIPLERI } & \multicolumn{4}{|c|}{ YOLCULAR } \\
\hline & $\mathbf{N}$ & Ortalama & $\begin{array}{l}\text { Standart } \\
\text { Sapma }\end{array}$ & $\mathbf{N}$ & Ortalama & $\begin{array}{l}\text { Standart } \\
\text { Sapma }\end{array}$ & $\begin{array}{l}\text { Ortalama } \\
\text { farkı }\end{array}$ \\
\hline 1 & 264 & 5,3030 & 1,27533 & 456 & 4,6383 & 1,48198 & 0,6647 \\
\hline 2 & 264 & 4,7045 & 1,42620 & 456 & 4,0329 & 1,48879 & 0,6716 \\
\hline 3 & 264 & 5,3220 & 1,20776 & 456 & 5,3904 & 1,34125 & $-0,0684$ \\
\hline 5 & 264 & 4,9167 & 1,38180 & 456 & 4,3268 & 1,74678 & 0,5899 \\
\hline 6 & 264 & 5,0492 & 1,35988 & 456 & 4,7741 & 1,60476 & 0,2751 \\
\hline 7 & 264 & 5,8712 & 1,17907 & 456 & 5,1732 & 1,45807 & 0,698 \\
\hline 8 & 264 & 5,5000 & 1,35938 & 456 & 4,5680 & 1,53200 & 0,932 \\
\hline 9 & 264 & 5,5871 & 1,28163 & 456 & 4,4868 & 1,54914 & 1,1003 \\
\hline 10 & 264 & 5,6364 & 1,18465 & 456 & 4,8575 & 1,41401 & 0,7789 \\
\hline 11 & 264 & 5,2273 & 1,28809 & 456 & 4,8531 & 1,42440 & 0,3742 \\
\hline
\end{tabular}




$\begin{array}{llllllll}12 & 264 & 5,2803 & 1,37779 & 456 & 4,9276 & 1,44998 & 0,3527 \\ 13 & 264 & 4,9621 & 1,64493 & 456 & 4,8421 & 1,42090 & 0,120 \\ 14 & 264 & 5,2992 & 1,25671 & 456 & 5,0154 & 1,32507 & 0,2838 \\ 15 & 264 & 5,6894 & 1,16758 & 456 & 5,0724 & 1,47105 & 0,6170 \\ 16 & 264 & 5,4962 & 1,21773 & 456 & 5,5066 & 1,35710 & -0,0104 \\ 17 & 264 & 5,2917 & 1,37127 & 456 & 5,2719 & 1,35896 & 0,0198 \\ 19 & 264 & 4,9356 & 1,52533 & 456 & 4,2500 & 1,52741 & 0,6856 \\ 20 & 264 & 4,7273 & 1,56769 & 456 & 3,9561 & 1,54715 & 0,7712 \\ 21 & 264 & 5,6174 & 1,31727 & 456 & 3,9825 & 1,62255 & 1,6349 \\ 22 & 264 & 5,3523 & 1,33145 & 456 & 4,6184 & 1,46430 & 0,7339\end{array}$

"Kabin ekipleri temiz ve düzgün görünüşlüdür", "Kabin ekipleri hiçbir zaman yolcu isteklerini yerine getiremeyecek kadar meşgul değillerdir", "kabin ekipleri yolculara karşı naziktir" ve "kabin ekipleri yolcuların sorularına cevap verebilecek bilgiye sahiptir" önermelerinde, kabin ekiplerinin ve yolcuların verdiği cevapların ortalama farkları göreli olarak en azdır ve istatistiksel olarak anlamlı bir fark oluşturmamaktadır. En büyük farkları ise "uçuş esnasında sunulan ikram malzemeleri kalitelidir", "yolculara hatasız hizmet sunmak için sürekli çalışır" ve "kabin ekipleri servise başlama zamanını yolcuların ihtiyaçlarına göre ayarlamaktadır" önermeleri oluşturmaktadır. Diğer önermelerde ise 0,2751 ile 0,932 arasında değişen ortalama farklılıkları tespit edilmiştir.

\subsection{6. İ̧ ve Dış Müşteri Verilerine Yönelik Normallik Testleri}

Yolcu ve kabin ekiplerinin verilerinin normal dağılıma uygun olup olmadığını anlamak için Shapiro-Wilk testi yapılmış ve bu test sonuçlarına göre veriler normal dağılmadığı görülmektedir. Bu sebeple diğer bir normallik göstergesi olan çarpıklık ve basıklık değerlerine bakılmıştır. Bu analizler; Tablo 9, Tablo 10, Tablo11 ve Tablo 12'de gösterilmiştir.

\section{Tablo 9: Normallik Testi (Yolcu Verileri)}

$\begin{array}{llll}\text { Yolcu Verileri } & \begin{array}{l}\text { Shapiro-Wilk } \\ \text { İstatistik }\end{array} & \text { Veri Sayısı } & \text { Sig. } \\ \text { Fiziksel Özellikler } & 0,092 & 456 & 0,00 \\ \text { Güven } & 0,079 & 456 & 0,00 \\ \text { Heveslilik } & 0,076 & 456 & 0,00 \\ \text { Güvenilirlik } & 0,082 & 456 & 0,00 \\ \text { Empati } & 0,080 & 456 & 0,00\end{array}$


Tablo 10: Normallik Testi (Yolcu Verileri)

\begin{tabular}{llll} 
Kabin Ekibi Verileri & $\begin{array}{l}\text { Shapiro-Wilk } \\
\text { İstatistik }\end{array}$ & Veri Sayısı & Sig. \\
\hline Fiziksel Özellikler & 0,101 & 264 & 0,00 \\
Güven & 0,136 & 264 & 0,00 \\
Heveslilik & 0,075 & 264 & 0,00 \\
Güvenilirlik & 0,094 & 264 & 0,00 \\
Empati & 0,079 & 264 & 0,00
\end{tabular}

Tablo 11: Kabin Ekibi Verilerinin Basıklık-Çarpıklık Değerleri

\begin{tabular}{|c|c|c|c|c|c|c|c|c|c|c|}
\hline \multirow[b]{2}{*}{$\begin{array}{l}\text { Veri } \\
\text { Sayısı }\end{array}$} & \multicolumn{2}{|c|}{ Fiziksel Özellikler } & \multicolumn{2}{|l|}{ Güven } & \multicolumn{2}{|l|}{ Heveslilik } & \multicolumn{2}{|c|}{ Güvenilirlik } & \multicolumn{2}{|l|}{ Empati } \\
\hline & İstatistik & $\begin{array}{l}\text { Standart } \\
\text { Hata }\end{array}$ & İstatistik & $\begin{array}{l}\text { Standart } \\
\text { Hata }\end{array}$ & İstatistik & $\begin{array}{l}\text { Standart } \\
\text { Hata }\end{array}$ & İstatistik & $\begin{array}{l}\text { Standart } \\
\text { Hata }\end{array}$ & İstatistik & $\begin{array}{l}\text { Standart } \\
\text { Hata }\end{array}$ \\
\hline $\begin{array}{l}\text { Aritmetik } \\
\text { Ort. }\end{array}$ & 5,10 & 0,063 & 5,38 & 0,066 & 5,27 & 0,065 & 5,44 & 0,061 & 5,15 & 0,07 \\
\hline Ortanca & 5,33 & & 5,60 & & 5,25 & & 5,50 & & 5,25 & \\
\hline $\begin{array}{l}\text { Tepe } \\
\text { Değer }\end{array}$ & 7 & & 7 & & 7 & & 7 & & 7 & \\
\hline Varyans & 1,06 & & 1,16 & & 1,12 & & 0,98 & & 1,41 & \\
\hline $\begin{array}{l}\text { Std. } \\
\text { Sapma }\end{array}$ & 1,03 & & 1,07 & & 1,06 & & 0,99 & & 1,18 & \\
\hline Çarpıklık & $-0,39$ & 0,15 & $-0,83$ & 0,15 & $-0,43$ & 0,15 & $-0,48$ & 0,15 & $-0,50$ & 0,15 \\
\hline Basıklık & $-0,27$ & 0,29 & 0,15 & 0,29 & $-0,70$ & 0,29 & 0,05 & 0,29 & $-0,20$ & 0,29 \\
\hline
\end{tabular}

Kabin ekiplerinin verilerine bakıldığında çarpıklık değerlerinin $\pm 1,00$ aralığında olduğu görülmektedir. Bu durum verilerin normal dağıldığını yani parametrik testler için veriler uygundur denilebilir (Leech ve Diğerleri, 2005: 21).

\section{Tablo 12: Yolcu Verilerinin Basıklık-Çarpıklık Değerleri}

\begin{tabular}{|c|c|c|c|c|c|c|c|c|c|c|}
\hline \multirow[b]{2}{*}{$\begin{array}{l}\text { Veri } \\
\text { Sayısı }\end{array}$} & \multicolumn{2}{|c|}{ Fiziksel Özellikler } & \multicolumn{2}{|l|}{ Güven } & \multicolumn{2}{|c|}{ Heveslilik } & \multicolumn{2}{|c|}{ Güvenilirlik } & \multicolumn{2}{|l|}{ Empati } \\
\hline & İstatistik & $\begin{array}{l}\text { Standart } \\
\text { Hata }\end{array}$ & İstatistik & $\begin{array}{l}\text { Standart } \\
\text { Hata }\end{array}$ & İstatistik & $\begin{array}{l}\text { Standart } \\
\text { Hata }\end{array}$ & İstatistik & $\begin{array}{l}\text { Standart } \\
\text { Hata }\end{array}$ & İstatistik & $\begin{array}{l}\text { Standart } \\
\text { Hata }\end{array}$ \\
\hline $\begin{array}{l}\text { Aritmetik } \\
\text { Ort. }\end{array}$ & 4,68 & 0,53 & 4,66 & 0,60 & 4,87 & 0,05 & 5,21 & 0,05 & 4,20 & 0,59 \\
\hline Ortanca & 4,66 & & 4,60 & & 5 & & 5,25 & & 4,25 & \\
\hline $\begin{array}{l}\text { Tepe } \\
\text { Değer }\end{array}$ & 7 & & 7 & & 7 & & 7 & & 7 & \\
\hline Varyans & 1,30 & & 1,67 & & 1,48 & & 1,36 & & 1,61 & \\
\hline $\begin{array}{l}\text { Std. } \\
\text { Sapma }\end{array}$ & 1,14 & & 1,29 & & 1,21 & & 1,16 & & 1,27 & \\
\hline Çarpıklık & $-0,41$ & 0,11 & $-0,36$ & 0,11 & $-0,50$ & 0,11 & $-0,50$ & 0,11 & $-0,14$ & 0,11 \\
\hline Basıklık & 0,23 & 0,22 & $-0,81$ & 0,22 & 0,37 & 0,22 & 0,26 & 0,22 & $-0,16$ & 0,22 \\
\hline
\end{tabular}


Yine Kabin ekibi verilerine benzer bir şekilde yolcu verilerinin basıklık değerleri de $\pm 1,00$ arasında olduğundan bu veriler içinde dağılımın normal olduğu söylenebilir (Leech ve Diğerleri, 2005: 21).

\subsubsection{Hizmet Kalitesi Boyutlarına Göre Kabin Ekibi ve Yolcular Arasındaki Algı Farklılıklarını Ölçmeye Yönelik T Testi}

Kabin ekipleri ile yolcuların hizmet kalitesi boyutlarını algılamasındaki farklar incelenmiştir. Bunagörehizmetkalitesininbeşboyutununtamamındakabinekipleriileyolculararasında0,05 anlamlılıkdüzeyindeanlamlıfarkolduğugörülmüştür.Boyutlararasıortalamalarabakıldığında söz konusu beş hizmet kalitesi boyutunun tamamında kabin ekiplerinin algı ortalamalarının yolcu algı ortalamalarından anlamlı derecede yolcu skorlarından daha fazla olduğu görülmektedir.Hizmetkalitesinintümboyutlarında,7'lilikertölçeğineg öreskorlarhemkabin ekipleri hem yolcular tarafindan verilen skorlar işletme açısından olumlu olarak değerlendirilebilir. Fakat tüm boyutlarda yolcular, kabin ekiplerine göre daha düşük skorlar vermişlerdir.

Tablo 13: Hizmet Kalitesi Boyutlarına Göre Kabin Ekibi ve Yolcular Arasındaki Algı Farklılıklarını Ölçmeye Yönelik T Testi

\begin{tabular}{|c|c|c|c|c|c|}
\hline & & $\mathbf{t}$ & df & Sig.(2-tailed) & Sonuç \\
\hline Fiz. Özellikler & $\begin{array}{l}\text { Varyansların eşit } \\
\text { olmadığı varsayımı }\end{array}$ & $-4,958$ & 718 & 0,000 & $\mathrm{HO}=\mathrm{Kabul}$ \\
\hline Güven & $\begin{array}{l}\text { Varyansların eşit } \\
\text { olmadığı varsayımı }\end{array}$ & $-7,999$ & 630,736 & 0,000 & $\mathrm{HO}=\mathrm{Kabul}$ \\
\hline Heveslilik & $\begin{array}{l}\text { Varyansların eşit } \\
\text { olduğu varsayımı }\end{array}$ & $-4,523$ & 718 & 0,000 & $\mathrm{HO}=\mathrm{Kabul}$ \\
\hline Güvenilirlik & $\begin{array}{l}\text { Varyansların eşit } \\
\text { olmadığı varsayımı }\end{array}$ & $-2,771$ & 622,668 & 0,006 & $\mathrm{HO}=\mathrm{Kabul}$ \\
\hline Empati & $\begin{array}{l}\text { Varyansların eşit } \\
\text { olduğu varsayımı }\end{array}$ & -9 & 718 & 0,000 & $\mathrm{HO}=\mathrm{Kabul}$ \\
\hline
\end{tabular}

Tablo 14: Hizmet Kalitesi Boyutlarına Göre Kabin Ekibi ve Yolcuların Faktör Ortalama Skorları

$\begin{array}{lllll}\text { Faktör } & \text { Kabin Ekibi } & & \text { Yolcular } \\ & \text { Ortalama } & \text { Std. Sapma } & \text { Ortalama } & \text { Std. Sapma } \\ \text { Fiziksel Özellikler } & 5,1098 & 1,031 & 4,6871 & 1,141 \\ \text { Güven } & 5,3848 & 1,078 & 4,6658 & 1,294 \\ \text { Heveslilik } & 5,2765 & 1,060 & 4,8701 & 1,216 \\ \text { Güvenilirlik } & 5,4441 & 0,993 & 5,2166 & 1,169 \\ \text { Empati } & 5,1581 & 1,189 & 4,2018 & 1,271\end{array}$

\subsubsection{Kabin Ekiplerinin ve Yolcuların Eğitim Durumlarına Göre Hizmet KalitesiAlgıları}

Aşağıda kabin ekiplerinin ve yolcuların eğitim düzeylerinin hizmet kalitesi algısı üzerin- 
deki etkileri incelenmiştir. Kabin ekiplerinin eğitim ile ilgili verileri incelendiğinde lise mezunu sayısının 28 olduğu görülmüştür. Parametrik testlerin varsayımlarının karşılanabilmesi için genel olarak 30 ve üstü veri gereklidir (Can, 2018: 25). Bu sebeple kabin ekiplerinin verilerinin ölçülmesinde Kruskall Wallis testi kullanılmıştır. Ayrıca kabin ekibi verilerinde lisansüstü eğitimi olan sadece 3 kişinin olmasından dolayı analizlerde bu gruba yer verilmemiştir.

Tablo 15: Kabin Ekiplerinin Eğitim Düzeyleri ile Hizmet Kalitesi Boyutları Arasındaki ilişkiyi gösteren Kruskal- Wallis Test Sonuçları

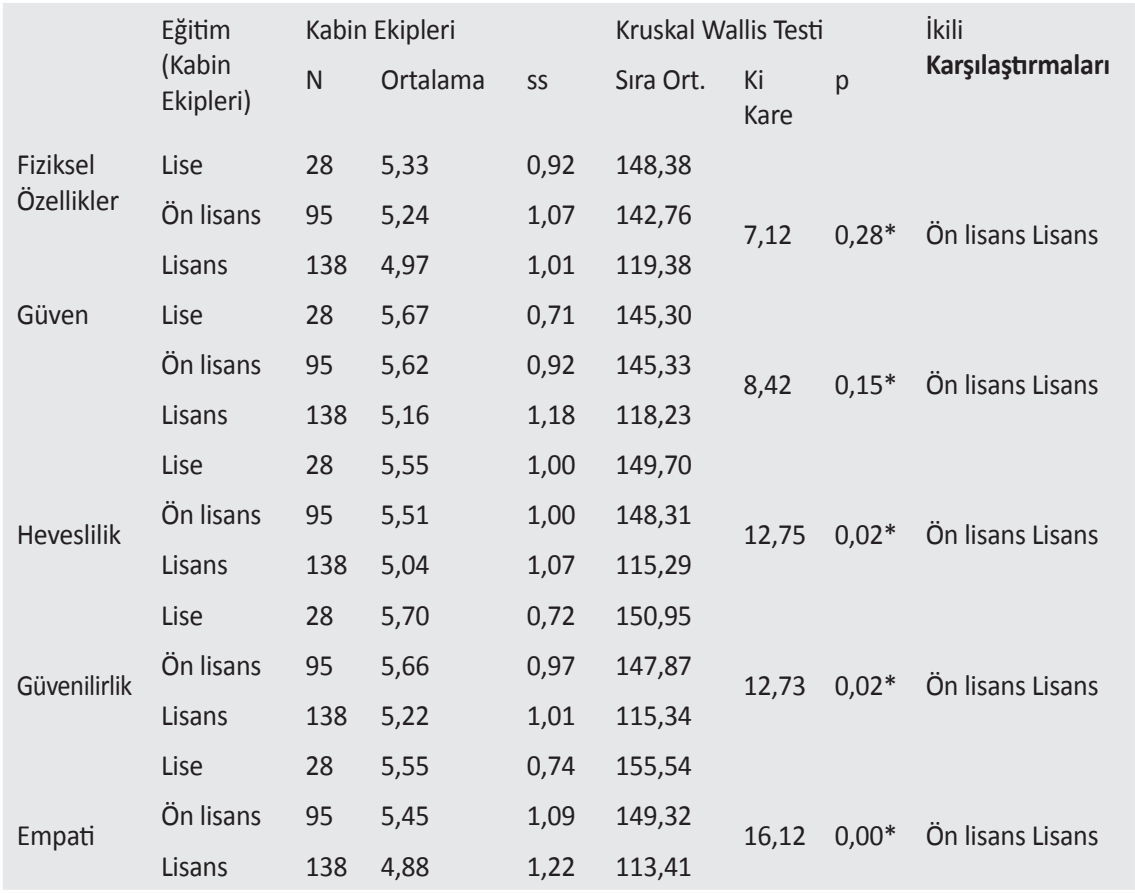

Yapılan Kruskall Wallis testi sonucunda kabin ekiplerinin eğitim düzeyleri ile hizmet kalitesi algılarıarasındaanlamlıfarkbulunmuştur.Bufarkınhangiboyutlararasındaolduğunugörmek için Mann Whitney $U$ testi yapılmıştır. Yapılan analiz sonucunda elde edilen veriler aşağıda tablodagösterilmiştir.

Tablo 16: Kabin Ekiplerinin Eğitim Düzeyleri ile Hizmet Kalitesi Boyutları Arasındaki iliş̧kiyi gösteren Mann Whitney U Testi Sonuçları

\begin{tabular}{|c|c|c|c|c|c|c|c|}
\hline & Eğitim & $\mathrm{N}$ & Sira Ort. & Sıra Toplamı & U & Z & $P$ \\
\hline Fiziksel & Ön Lisans & 95 & 129,13 & 12267 & 5402 & $-2,290$ & $0,02^{*}$ \\
\hline Özellikler & Lisans & 138 & 108,65 & 14993 & & & \\
\hline \multirow[t]{2}{*}{ Güven } & Ön Lisans & 95 & 131,38 & 12481 & 5188 & $-2,709$ & $0,00^{*}$ \\
\hline & Lisans & 138 & 107,10 & 14779 & & & \\
\hline
\end{tabular}




\begin{tabular}{llllllll} 
Heveslilik & Ön Lisans & 95 & 134,45 & 12772 & 4897 & $-3,289$ & $0,00 *$ \\
& Lisans & 138 & 104,99 & 14488 & & & \\
Güvenilirlik & Ön Lisans & 95 & 133,87 & 12718 & 4952 & $-3,183$ & $0,00 *$ \\
& Lisans & 138 & 105,38 & 14543 & & & \\
\multirow{2}{*}{ Empati } & Ön Lisans & 95 & 135,55 & 12877 & 4792 & $-3,495$ & $0,00 *$ \\
& Lisans & 138 & 104,23 & 14383 & & &
\end{tabular}

${ }^{*} p<0,05$

Yapılan test sonucunda ön lisans ve lisans mezunlarının hizmet kalitesi algıları arasında anlamlı fark olduğu görülmektedir. Yolcular için ise lise, ön lisans, lisans ve lisansüstü mezunu katılımcıların hizmet kalitesi algılarını gösteren tek yönlü Anova testi kullanımıştrr.

Tablo 17: Yolcuların Eğitim Düzeyleri ile Hizmet Kalitesi Boyutları Arasındaki ílişkiyi Gösteren Tek Yönlü Anova Testi

\begin{tabular}{|c|c|c|c|c|c|c|}
\hline & & $\begin{array}{l}\text { Kareler } \\
\text { Toplamı }\end{array}$ & df & $\begin{array}{l}\text { Kareler Toplamı } \\
\text { Karesi }\end{array}$ & $\mathbf{F}$ & $p$ \\
\hline B1 & $\begin{array}{l}\text { Gruplar Arası } \\
\text { Grup İçi Toplam }\end{array}$ & $\begin{array}{l}9,072 \\
584,625 \\
593,707\end{array}$ & $\begin{array}{l}5 \\
450 \\
455\end{array}$ & $\begin{array}{l}1,504 \\
1,300\end{array}$ & 1,157 & 0,330 \\
\hline B2 & $\begin{array}{l}\text { GruplarArası } \\
\text { Grup İçi } \\
\text { Toplam }\end{array}$ & $\begin{array}{l}10,114 \\
751,992 \\
762,106\end{array}$ & $\begin{array}{l}5 \\
450 \\
455\end{array}$ & $\begin{array}{l}2,023 \\
1,671\end{array}$ & 1,210 & 0,303 \\
\hline B3 & $\begin{array}{l}\text { Gruplar Arası } \\
\text { Grup İçi Toplam }\end{array}$ & $\begin{array}{l}11,324 \\
662,289 \\
673,614\end{array}$ & $\begin{array}{l}5 \\
450 \\
455\end{array}$ & $\begin{array}{l}2,265 \\
1,472\end{array}$ & 1,539 & 0,176 \\
\hline B4 & $\begin{array}{l}\text { Gruplar Arası } \\
\text { Grup İçi Toplam }\end{array}$ & $\begin{array}{l}6,386 \\
616,416 \\
622,802\end{array}$ & $\begin{array}{l}5 \\
450 \\
455\end{array}$ & $\begin{array}{l}1,277 \\
1,370\end{array}$ & 0,932 & 0,460 \\
\hline B5 & $\begin{array}{l}\text { Gruplar Arası } \\
\text { Grup İçi Toplam }\end{array}$ & $\begin{array}{l}9,748 \\
666,869 \\
676,617\end{array}$ & $\begin{array}{l}5 \\
450 \\
455\end{array}$ & $\begin{array}{l}2,412 \\
1,608\end{array}$ & 1,500 & 0,188 \\
\hline
\end{tabular}

Analiz sonuçlarına göre 0,05 anlamlılık düzeyinde yolcuların eğitim düzeyleri ile kalite algıları arasında anlamlı bir fark bulunmamıştır.

\section{SONUÇ VE ÖNERILER}

Sivil hava taşımacılığı, 1950'li yıllardan itibaren gösterdiği gelişme ile turizm endüstrisinin bugünkü halini almasında önemli rol oynamıştır. Küreselleşme ve liberalleşme ile birçok ülkede devlet ve özel havayolları birbirleri ile ve diğer ülkelerin havayolu işletmeleri ile yoğun rekabet içerisine girmişlerdir. Sadece düşük fiyat ile rekabet etmek mümkün olmadığından, müşterilere yüksek hizmet kalitesi sunumu işletmenin rekabet gücüne önemli katkısı bulunmaktadır.

Araşttrmanın sonuçlarına göre yolcu ve kabin ekipleri "kabin ekipleri temiz ve düzgün görünüşlüdür", "kabin ekipleri hiçbir zaman yolcu isteklerini yerine getiremeyecek kadar 
meşgul değillerdir", "kabin ekipleri yolculara karşı naziktir" ve "kabin ekipleri yolcuların sorularına cevap verebilecek bilgiye sahiptir" önermelerine verdikleri cevaplar arasında anlamlı fark görülmemiştir. Önermelere tek tek bakıldığında, kabin ekiplerinin temiz ve düzgün görünüşlü olması önermesine yolcuların verdiği cevap ortalaması 5,3904, kabin ekiplerinin ise 5,3220'dir. Kabin ekiplerinin belli dönemlerde üniformalarının yenilenmesi ve uçuşlarına gitmeden önce kontrol edilmeleri hem yolcuların hem kabin ekibinin yüksek sayılabilecek bu değerlerde hemfikir olmasına neden olmuş olabilir. Diğer önermeler ise kabin ekiplerinin etkili ve sürekli bir eğitim süreci içerisinde olmalarından kaynaklanabilir.

Araştırmada Hatipoğlu ve Işık, (2015: 307)'ın çalışmasına benzer şekilde yolcuların hizmet kalitesi algısı ile eğitim durumları arasında anlamlı bir fark bulunmamıştır. Fakat kabin ekiplerinin eğitim durumları ile hizmet kalitesi algıları arasında anlamlı fark olduğu görülmüştür. Fakat bu fark sadece ön lisans ve lisans mezunları arasında çıtığından, normal dağılım gösteren örneklem grupları ile tekrar çalışma yapııması faydalı olabilir.

Uçuş esnasında sunulan ikram malzemeleri kalitelidir", "yolculara hatasız hizmet sunmak için sürekli çalışır" ve "kabin ekipleri servise başlama zamanını yolcuların ihtiyaçlarına göre ayarlamaktadır" önermeleri hem göreli en düşük ortalamaya sahip önermeler hem de yolcular ile kabin ekipleri arasındaki farkın en çok olduğu önermelerdir. Kabin ekiplerinin hizmetlerini işletme tarafindan belirlenen standartlara göre yapmakta ve servis sırasında olası yolcu taleplerine göre trolleylerini (servis arabası) hazırlamaktadır. Ayrıca araştırma yapılan işletme belli dönemlerde hizmetlerde ve menülerde değişikliğe gitmektedir. Fakat araştırma sonuçlarına göre yolcuların bu uygulamaları yeterli görmediği söylenebilir. Sunulan yiyeceklerin kalitesi yolcular tarafindan başarılı olarak değerlendirilmemiştir. Sunulan ikram malzemeleri değerlendirildiğinde menülerin dünyaca kabul görmüş markalardan oluştuğu görülmektedir. Fiyat ile kalite algısı arasındaki ilişki düşünüldüğünde bu durumun sebebi fiyat- kalite dengesinin yolcuların beklentisinin uzağında olduğu söylenebilir. Bu bağlamda firmalara bu dengenin kurulması ve sürdürülmesi önerilebilir.

Araştırma yapılan işletmenin kabin hizmetlerinin, yolcular tarafindan genel olarak kaliteli algılandığı söylenebilir. Fakat sunulan ikram malzemelerindeki fiyat-kalite dengesinin daha tatmin edici düzeyde sağlanması kalite algısının yükselmesini sağlayabilir ve müşteri memnuniyetini artırabilir. Fiyat ve kalite algısı müşteri tercihlerini önemli oranda etkileyebilmektedir. Bu sebeple havayolu işletmeleri bu hususa da dikkat etmelidir.

Çalışmanın sonuçlarına göre hizmet kalite değerlendirmesini sadece iş gören üzerinde yapmak kalite algı skorlarının beklenenden fazla çıkmasına neden olmaktadır. Bu sonuç Chen ve Chang, (2005: 83) yaptı̆̆ı çalışmayla benzerlik göstermektedir. Bu sebeple sadece iş gören ile yapılacak hizmet kalitesini ölçmeye yönelik araştırmalar yanıltıcı sonuçlar verebilir.

Araştırma sadece düşük maliyetli tek bir havayolu işletmesi üzerinde yapılmıştır. Farklı düşük maliyetli havayollarının birlikte değerlendirilmesi ile yapılacak daha kapsamlı çalışmaların literatüre katkı sağlayacağı düşünülmektedir.

Araştrrma sadece düşük maliyetli tek bir havayolu işletmesi üzerinde yapılmıştr. Farklı düşük maliyetli havayollarının birlikte değerlendirilmesi ile yapılacak daha kapsamlı çaIışmaların literatüre katkı sağlayacağı düşünülmektedir. 


\section{KAYNAKÇA}

AKTEPE, E. (2016). Genel İ̧̧letme (6. b.). Ankara: Nobel Yayınları.

ALPAR, R. (2017). Çok Değişkenli İstatistiksel Yöntemler (5. Baskı b.). Ankara: Detay Yayınları.

ALTAN, Ş. ve Atan, M. (2004). Bankacılık sektöründe toplam hizmet kalitesinin SERVQUAL analizi ile ölçümü. Gazi Üniversitesi Iktisadi ve Idari Bilimler Fakültesi Dergisi, 1, 17-32.

ALTUNıŞıK, R. (2009). Turizm İşletmelerinde Pazarlamanın Temelleri ve İki Farklı Pencereden Pazarlama Yönetimi: Üretici ve Tüketici Bakışı. İçinde C. Avcıkurt, Ş. Demirkol, ve B. Zengin (Editörler), Turizm İşletmelerinin Pazarlamasında 7P ve 7C (ss. 7-47). İstanbul: Değişim Yayınları.

ALTUNIŞIK, R. ve Karataş, A. (2015). Turizm İşletmeleri ve Pazarlama Stratejileri. İçinde B. Zengin, ve Ş. Demirkol (Editörler), Turizm Iş̧letmeleri (3. b., s. 543-563). İstanbul: Değişim Yayınları.

BELOBABA, P., Odoni, A. ve Barnhart, C. (2016). The Global Airline Industry (2. b.). Chichester: John Wiley ve Sons, Ltd.

BROWN, S. W., Gummesson, E., Edvardsson, B. ve Gustavsson, B. (1991). Service Quality: Multidisciplinary and Multinational Perspectives. Lexington: Lenxington Books.

BÜLBÜL, H. ve Demirer, Ö. (2008). Hizmet Kalitesi Ölçüm Modelleri Servqual ve Servperf'in Karşılaştrılmalı Analizi. Selçuk Üniversitesi Sosyal Bilimleri Enstitüsü Dergisi(20), 181-198.

CAN,A.(2018).SPSSileBilimselAraşttrmaSürecindeNicelVeriAnalizi(6.b.).Ankara:PegemAkademi.

CHEN, F.-Y. ve Chang, Y.-H. (2005). Examining Airline Service Quality From A Process Perspective. Journal of Air Transport Managment, 11(2), 79-87.

CHIOU, Y.-C. ve Chen, Y.H. (2010). Factors Influencing The Intentions of Passengers Regarding Full Service and Low Cost Carriers: A note. Journal of Air Transport Managment, 16(4), 79-87.

COŞKUN, R., Altunışık, R., Bayraktaroğlu, S. ve Yıldırım, E. (2015). Sosyal Bilimlerde Bilimsel Araştırma Yöntemleri (8. Baskı b.). Sakarya: Sakarya Yayıncılık.

CRONIN,J.veTaylor,S.A.(1992). MeasuringServiceQuality:AReexaminationandExtension.Journalof Marketing,55-68.

FRAYMAN, M. A. (2002). Quality and Process Improvement. NY: Cengage Learning.

GILLEN, D. ve Morrison, W. (2003). Bundling, Integration and The Delivered Price of Air Travel: Are Low cost Carriers Full Service Competitors? Journal of Air Transport Managment, 9(1), 15-23.

GILLEN, D. ve Lall, A. (2004). Competitive Advantage of Low-Cost Carriers: Some Implications for Airports.

Journal of Air Transport Managment, 10(1), 41-50.

GÖKTEPE,H.(2007).HavaTaşımacılığıSektöründeRekabetHukukuKurallarınınUygulanması.SosyalBilimler Dergisi(1),213-240.

GRÖNROSS, C. (1984). A Service Quality Model and Its Marketing Implications. European Journal of Marketing, 18(4), 36-44.

GÜRBÜZ,S.veŞahin,F.(2017).SosyalBilimlerdeAraştırmaYöntemleriFelsefe-Yöntem-Analiz(4.b.).

Ankara: Seçkin Yayıncılık.

HATIPOĞLU, S. ve Işık, E. S. (2015). Havayolu Ulaşımında Hizmet Kalitesinin Ölçülmesi: İç Hatlarda Bir Uygulama. Kahramanmaraş Sütçü Imam Üniversitesi Sosyal Bilimler Dergisi, 12(2), 293-312.

İBiK, Ö. A. (2006). Rekabet Ortamında Hizmet Kalitesinin Önemi ve Bir Havayolu İşletmesinde Hizmet Kalitesinin Gerçekleştirilmesine Yönelik Bir Uygulama Basılmamış Yüksek Lisans Tezi. Kocaeli Üniversitesi Fen Bilimleri Enstitüsü.

JAIN, J. P. (2001). Quality Control and Total Quality Managment. New Delhi: McGraw-Hill Education.

JAIN, S. K. ve Gupta, G. (2004). Measuring Service Quality: Servqual vs. Servperf Scales. Vikalpa, 29(2), 25-38. KOÇOĞLU, C. M. ve Aksoy, R. (2012). Hizmet Kalitesinin Servperf Yöntemi ile Ölçülmesi: Otobüs İşletmeleri

Üzerinde Bir Uygulama. Akademik Bakış Dergisi(29), 1-25.

KOTLER, P. R. (2014). Marketing for Hospitality and Tourism (6. b.). Edinburgh Gate: Pearson.

LEECH,N.L.,Barrett,K.C.veMorgan,G.A.(2005).SPSSforIntermediateStatistics:UseandInterpretation (2.b.).NewJ ersey:LawrenceErlbaumAssociates,Inc.

OKUMUŞ, A. ve Asil, H. (2007). Havayolu Taşımacılığında Yerli ve Yabancı Yolcuların Memnuniyet Düzeylerine Göre Beklentilerinin İncelenmesi. Kocaeli Üniversitesi Sosyal BilimlerEnstitüsü Dergisi, 1(13), 152-175.

ÖMÜRBEK, V. ve Kınay, B. (2013). Havayolu Taşımacılığı Sektöründe TOPSIS Yöntemiyle Finansal Performans Değerlendirmesi. Süleyman Demirel Üniversitesi iktisadi ve Idari Bilimler Fakültesi Dergisi, 18(3), 343-363. 
PAGE, S. J. (2016). Turizm İşletmeciliği (5. b.). Ankara: Nobel.

PARASURAMAN, A., Zeithaml, V. A. ve Berry, L. B. (1985). A conceptual model of service quality and its implications for future research. The Journal of Marketing, 41-50.

PARASURAMAN, A., Zeithmal, V. A. ve Berry, L. L. (1988). Servqual: A Multi Item Scale for Measuring Consumer Perception of Service Quality. Journal of Retailing, 64(11), 12-37.

PEKKAYA, M. ve Akıllı, F. (2013). Hava yolu Hizmet Kalitesinin SERVPERF-SERVQUAL Ölçeği ile Değerlendirmesi ve İstatistiksel Analizi. AiBÜ-iiBF Ekonomik ve Sosyal Araşttrmalar Dergisi., 1(9), 75- 96.

RHODEN,S., Ralston, R.velneson,E.M.(2008).CabinCrewTrainingtoControlDispruptiveAirlinePassenger Behavior: A Cause of Tourism Concern? Tourism Managment, 29,538-547.

RUST, R. T. ve Oliver, R. L. (1994). Service Quality: Insights and Managerial Implications from the Frontier. R.

T.RustveR.L.Oliveriçinde,ServiceQuality:NewDirectionsinTheoryandPractice(s.1-20).Thousand Oaks: Sage Publications, Inc.

SCHINEIDER, B. ve White, S. S. (2004). Service Quality; Research Perspectives. Thousand Oaks: Sage Publications Ltd.

SÜER, İ. (2014). Pazarlama ilkeleri. Ankara: Nobel Akademik Yayıncılık.

USTA, R. ve Memiş, S. (2009). Hizmet Kalitesi ve Marka Bağlılı̆̆ Arasındaki Illişki Üzerine Müşteri Tatmininin Aracilık Etkisi. Atatürk Üniversitesi IïF Dergisi, 23(4), 87-108.

YILDIZ,O.veErdil,T.S.(2013).TürkiyeHavayoluTaşımacılığıSektöründeHizmetKalitesininKarşılaştırılmalı Ölçümlenmesi. Öneri Dergisi, 10(39),89-100.

ZEITHAML, V. A. (1988). Consumer Perceptions of Price, Quality, and Value: A Means-End Model and Synthesis of Evidence. Journal of Marketing, 52(3), 2-22.

ZENGIN,E.veErdal,A.(2000).HizmetSektöründeToplamKaliteYönetimi.JournalofQafqazUniversity,3(1), 43-56.

ZENGIN, B., Şengel, Ü., Yılmazer, A., (2017) "Uluslararası Seyahat İşletmeciliğine Giriş”, Uluslararası Seyahat İşletmeciliğiKitabıiçinde1.Bölüm,Ed.:B.Zengin,M.Sarışık,C.Avcıkurt,DETAYYayıncılık,Ankara, Türkiye.

WEB-1, http://www.iata.org/publications/Documents/iata-annual-review-2017.pdf (ET: 22 .01 .2018)

WEB-2, http://www.milliyet.com.tr/youtube-da-en-cok-izlenen-reklam/ekonomi/detay/2068988/defaul

t.htm adresinden alındı (ET:22.01.2018).

WEB-3, http://www.fifa.com/marketinghighlights/brazil2013/commercial-affiliates/fifapartners/emirates/index. html (ET:22.01.2018)

WEB-4,http://www.advertisingarchives.co.uk/detail/87514587/1/Magazine-Advert/BritishAirways/1980s(ET: 22.

WEB-5, http://web.shgm.gov.tr/tr/havacilik-personeli/2138-kabin-memuru (ET:23.01.2018)01.2018)

WEB-6, http://web.shgm.gov.tr/tr/havacilik-personeli/2138-kabin-memuru (ET:23.01.2018) 